\title{
State Authority and Lynching in Latin America
}

\author{
Giovanni B. Corvino
}

University of Turin. ORCID: 0000-0002-8191-3500. Email: giovanni.corvino@edu.unito.it

\begin{abstract}
Social scientists observed a significant increase in the number of lynchings in contemporary Latin America. The reasons for the rise are wide-ranging and conflicting. However, there are commonalities with the well-known cases of the United States of the nineteenth and twentieth centuries in which state legitimacy was the subject of intense debate. Therefore, this essay aims at observing why state intervention was deemed illegitimate in resolving local disputes that led to the vigilantes' use of this form of extra-legal violence.
\end{abstract}

Keywords

lynching, summary justice, governance, vigilantes, extra-legal violence

\section{INTRODUCTION - TODAY'S LYNCHINGS IN LATIN AMERICA}

Latin America has recently been considered among the most violent regions, due to the increasing number of crimes committed (UNODC, 2014), including lynching. According to the Consejo Ciudadano para la Seguridad Pública y la Justicia Penal A.C. (Martell, 2019), in 2018, as many as forty-two of the fifty cities with the highest homicide rate are in this geographical area, ten of these are in Brazil.

Despite this, the study of the contemporary practice of lynching - outside of the United States - has not received much attention from the academic community. Yet, as many scholars point out, cases attributable to the practice of lynching are increasing on a global scale and especially in Latin America (Pfeifer, 2017). Despite the difficulty of defining the phenomenon of lynching and distinguishing it from other forms of violence, it seems that the phenomenon has escalated considerably in various countries of the continent. The United Nations Mission in Guatemala (MINUGUA) only started to record the first incidents of lynching in 1996 (Girón, 2007), even though the practice had been known before, since $18^{\text {th }}$ century. With more than four hundred cases and about two hundred reported victims up to 2001 (MINUGUA, 2002), lynching would take root in Guatemala due to political instability born during the transition from a military to a democratic regime, after thirty-six years of civil war. Cases before the 1996 peace accords went unreported, and similar incidents of violence still occur today. According to the survey carried out by Guatemala's Human Rights Ombudsman, there have been no peaks in the number of episodes in recent years, maintaining an average number of about 130 cases per year, divided between about a hundred injured and about thirty dead. However, 2013 was a shocking year, as there were 53 deaths, or more than once per week (Inter-American Commission on Human Rights, 2017, p. 177). 
In Venezuela, however, cases of lynching seem to be increasing rapidly. The first incidents knew date back to 1994 and were two isolated incidents, far from urban centers. However, the possibility of a form of private and immediate justice quickly gained widespread support, so much that it appeared to be the only solution to contrast the growing criminality (Schemo, 1996). Indeed, the Observatorio Venezolano de Conflictividad Social recorded around 200 cases in 2017 alone (OVC, 2017). Still, according to the French press, at least one person per day died from lynching that year (Cabrera, 2018). The U.S. press also disagrees with the data provided by the Venezuelan government, reporting a 650\% increase in lynching in 2016 (Venezuela Investigative Unit, 2017).

In Bolivia, the situation is even more alarming, partly due to the population's lack of trust in the Police (Yates, 2020). In addition, the Bolivian legal system has serious problems. Suffice it to say that in 2012 about half of the country's municipalities did not have an assigned judge, more than $70 \%$ lacked a public prosecutor, and more than 90\% lacked a public defender (Chávez, 2013; Consejo de Derechos Humanos, 2012, p. 10; Rojas, 2010). It is in this tremendous judicial vacuum that lynching increased day by day. According to the 2018 report of the Human Rights Watch Foundation:

Impunity has led to mob attacks, or lynchings, of alleged criminals. In May, a mob in the eastern city of San Julián entered a courtroom where a judge was questioning an alleged killer of a local woman, dragged the suspect outside, killed him, and hanged him in a tree. Many such lynchings go unpunished (Human Rights Watch, 2018, p.77).

There were 46 reported cases between November 2005 and January 2008 and 134 between 2008 and 2012. There was also an increase in 2013, with 70 incidents (an episode every five days or so) with 30 deaths (Armanda Global, 2014, p. 4). Brazil is probably the Latin American state where lynching finds most similarities with the U.S. phenomenon. Indeed, as in the last century happened in Georgia, Mississippi, Texas, and neighboring territories, in 2017, a mob of about 500 people lynched a woman in Novo Aripuanã with a modus operandi similar to that suffered by African Americans in North America (Allen, 2017). It is a growing phenomenon that has its origins in the abolition of slavery in 1888 and the subsequent establishment of the First Republic in 1889 (Pfeifer, 2017). Data between 1945 and 1998 reveal 2,579 lynching attempts, with 782 deaths and 439 injuries (Saccone, 2017). It is worth mentioning that, unfortunately, in Brazil, lynching is not reported in criminal statistics, as they become murders or personal injuries; therefore, the number could be even much higher (Saccone, 2017). An investigation by The Guardian (De Oliveira, 2016), based on the publication of local news and official records for violent deaths, reveals that 173 people lost their lives in 2016 - that is, almost one victim every two days - in the circumstances attributable to actual lynching.

As noted, these incidents in Latin America are on the rise in the $21^{\text {st }}$ century. What are the real causes behind this escalation? Is it really a sense of public insecurity and political instability that leads to such extreme violence? Consequently, is it a problem of governance and state legitimacy? The following paragraphs attempt to 
answer these questions by considering the facts reported by local newspapers and the emerging literature on the subject.

\section{THE ORIGINS OF THE PHENOMENON}

Even today, the definition of the term 'lynching' is a matter of debate within the scientific community. In the past, lynching referred to as a set of violent actions, including stoning, torture with hot irons, hanging, and the use of firearms, aimed at sanctioning conduct that deserved immediate community condemnation. It is, however, widely believed that the word 'lynching' has American origins, as it was in that territory that the most significant number of victims occurred between the end of the 19th century and the first half of the 20th century. Nevertheless, the literature on the lynching of African Americans in the United States repeatedly questioned the true origin of the practice, and the most comprehensive answer is given by Michael Pfeifer (2011) in his book The Roots of Rough Justice: Origins of American Lynching. According to the author, "the legal and cultural antecedents of American lynching were carried across the Atlantic by migrants from the British Isles to colonial North America" (p. 7), thus highlighting the colonial derivation of this form of violence that characterized the construction of American identity in the 20th century. Moreover, Pfeifer and other scholars have referred to this phenomenon as "extra-legal group assault and/or murder motivated by social control concerns" (Pfeifer, 2017, p. 1), thus extending the meaning of such aggression to the whole world because of the possible fields of application in which it could find relief, such as in the context of Latin America.

In this regard, the definition proposed by Berg and Wendt in Globalizing Lynching History: Vigilantism and Extra-legal Punishment from an International Perspective (2011, p.5) fits well with the Latin American issue, where lynching can be understood as: "[...] a form of extra-legal punishment, usually entailing death or severe physical harm, perpetrated by groups claiming to represent the will of the large community". The authors underline the premeditation of the act, highlighting its collective character and emphasizing a direct link with a potential demand for the death penalty implicit in the violence. In Lynching and Local Justice - Legitimacy and Accountability in Weak States, Jung and Cohen (2020, p. 5) take up this contribution and expand its meaning in:

a lethal, extra-legal group violence, perpetrated by ordinary people, intended to punish offenses to the community; or, more succinctly, community-based capital punishment, sometimes called the 'popular death penalty.

Therefore, anyone can instigate a lynching, as happened in the United States in the last century. Moreover, the intentionality of resorting to extra-legal action underlines the voluntary decision not to wait for state intervention and be the originator of the condemnation.

In Latin America, the vision of communal and autonomous justice can be seen as a legacy of the colonial era. Indeed, indigenous communities today claim, among other rights, the administration of justice within their territories. The desire to claim 
greater decision-making authority in local legal administration stems from the fracture between the state and local communities, which characterized the complex construction of the national state in Latin America (Morelli, 2007). The municipalism of colonial origin was transformed and strengthened during the crisis of the Spanish empire at the beginning of the 19th century, granting local communities - including indigenous ones - new powers, primarily that of administering justice. The local authorities' control explains the weakness of the nation-states during the $19^{\text {th }}$ century and the difficulty for them to take away from the former the jurisdictional attributes they gained during the colonial era in conjunction with the monarchy crisis. One of the new states' main difficulties was the slow and challenging transformation from an Old Regime jurisdictional system to a modern one based on the separation of powers and the centrality of the law. This difficulty also occurred because of the formidable indigenous communities' resistance to what would mean a loss of control in their territories.

The debate regarding the full recognition of the rights of indigenous nationalities (Stavenhagen, 2005) is still a subject of political discussion today. In 2004, the United Nations recognized many rights for indigenous people, including "respect for, and occupation of, a specific territory," recognition of a specific cultural identity, the right to self-identification, and to be considered as a distinct collectively victim of "subjugation, marginalization, dispossession, exclusion and discrimination" (Stavenhagen, 2005, p. 17). Although these rights have been included in many Latin American countries' constitutions, the right to judicial autonomy other than the state's was widely criticized. While it is true that during the period of the modern state expansion, indigenous communities lost many powers, the right to judicial autonomy distinct from that of the state - even though it is the result of ancient customs - is not accepted by those who claim unique sovereignty of the nation-state.

\section{STATE LEGITIMACY Vs. VIGILANTES' LEGITIMACY}

Lynching is a phenomenon that affects everyone indiscriminately, from mestizo communities to African American and indigenous communities, although it is apparently more frequent in poor and marginalized localities (Godoy, 2004).

According to Jung and Cohen $(2020$, p.3) it occurs when: "[...] states fail to provide governance, when non-state actors provide social services, or when community members must rely on self-help," and this seems to be in line with Godoy's thinking, who already in 2004 (p. 623) defined these episodes as: "[...] a new sort of violence originating at the bottom, which is purposeful, powerful, and political," contrary to the dominant literature that considered these episodes from a top-down point of view (e.g. carried out by the state against citizens through the police forces to calm down local tensions). Jung and Cohen's (2020) study show that the population tends to consider the presence of the state as illegitimate in the resolution of cases requiring lynching when the government proves to be, for example, corrupt or repressive. However, the perception of the legitimacy of state intervention is not 
damaged if non-state actors - such as vigilantes - intervene to resolve local disputes. Conversely, the state legitimacy of intervention continues to be stable in the minds of citizens if they feel they are not receiving proper support from the government. Still, vigilantes are considered unnecessary if they do not act immediately in the place of the state.

In the case of Latin America, lynching found fertile ground in a territory where state legitimacy was severely tested by the internal conflicts that marked its history. One thinks of the 30-year civil war in Guatemala, and the peace agreements concluded only in 1996, the failed coup d'état in Venezuela in 2002 against the government of Hugo Chávez, the lack of administrative resources in Bolivia, and the intense episodes of racial discrimination in Brazil. As argued by Prillaman:

The void created by weak, inefficient and inaccessible courts has been filled by a combination of mob action, vigilante justice, and law-and-order politicians tapping public frustration and exposing some of the more base impulses of society (Prillaman 2000, p. 172).

Consequently, it is precisely when a state's governance actions do not accomplish the expected results that its legitimacy is questioned. In this circumstance, the Police and other forces deployed by local authorities would be considered ineffective by the population (Jung and Cohen, 2020). Consequently, more trust and support would be given to non-state actors who, at that precise moment, take the place of the state in the administration of public safety. It was also the case in the United States in the 20th century, and indeed it is also thanks to this social insecurity thinking that the Ku Klux Klan and other vigilante groups gained wide acceptance.

Lynching, regardless of where it occurs, is supported by perceptions of (il)legitimacy, as "uncertainty over the lack of a monopoly can cause people to turn to self-organized dispute adjudication in the form of lynching, in which ordinary people - often spontaneously - mete out lethal punishment for interpersonal crimes" (Jung and Cohen, 2020, p. 25). Thus, the legitimacy of state sovereignty can be challenged by groups of people who self-organize to provide other services in addition to more stable governance, such as protection from criminal gangs. To cope with the increasing crime rate that characterized Latin America in the last decade, many citizens resorted to extra-legal violence to counter the actions of criminals, belatedly - or not - condemned by state laws. Guatemala (Bateson, 2013; Handy 2004), Brazil (Barbara, 2015), Bolivia (Goldstein, 2003, 2004), and Peru (BBC Mundo, 2004) have been the most studied countries, but Mexico (Melgar, 2013), Venezuela, Argentina (Peregil, 2014), and other neighboring states are also beginning to arouse interest (Zizumbo-Colunga, 2017), given the violence exercised by the new vigilante groups.

However, this is not an entirely new phenomenon: it can be observed as early as the early 1980s in Colombia, where, to counter the left-wing guerrillas advancing in the region, wealthy and right-wing landowners resorted to paramilitary organizations composed of vigilantes, who were guilty of various human rights violations (Mazzei, 2009). The study of vigilantism has been observed in a variety of disciplines, including history (Pfeifer, 2011), anthropology (Weston, 2020), sociology (Sundar, 2010), and 
political science (LeBas, 2013). However, there is still no commonly agreed definition (Jung and Cohen, 2020). Rosenbaum and Sederberg (1974, p. 542) defined it as "the taking of the law into one's own hands [that] consists of acts or threats of coercion in violation of the formal boundaries of an established sociopolitical order which, however, are intended by the violators to defend that order from some form of subversion." Their suggestion can no longer be considered current due to the ideological evolution underlying the constitution of vigilante groups. Indeed, more recent scholars such as Moncada $(2017$, p. 403) defined vigilantism as: "the collective use or threat of extra-legal violence in response to an alleged criminal act," but is it always a collective phenomenon?

Questioning a possible definition that brings together what was observed by many disciplines over the years, Bateson $(2020$, p. 4) defines vigilantism as "the extralegal prevention, investigation, or punishment of offenses." Therefore, state agents are not excluded from the possibility of promoting or tolerating violent actions that may occur individually or in groups. Furthermore, the scholar wants to clarify that extralegal and illegal are two different terms since "illegality requires only that an action violates the law. Extra legality requires that an action goes beyond the law, which implies an action that is moving in the same direction as the law, but exceeding its scope or severity" (Bateson, 2020, p. 5). Hence, considering the conceptual relationality that characterises vigilantism (Abrahams, 1998, p. 6) in its extra-legal character, state authorities can also operate in this direction, as happened in the United States in the $20^{\text {th }}$ century (Waldrep, 2002). The practice of lynching would thus be considered permissible, as it would guarantee an immediate sentence that would satisfy the popular will through the actions of vigilantes. The modus operandi with which violence is carried out does not change with geographical distance or after some time. What the international press reported about the recent case of Orlando Figuera proves: 'Figuera was stabbed six times, doused in gasoline, and burned alive [...] in the eastern Caracas neighborhood of Altamira' (Gilbert, 2017). Other 21st century cases are even more descriptive and similar to U.S. cases from the 19th and 20th centuries:

On October 20,2001, a crowd of peasants captured three men accused of stealing two cases of soda, some fertilizer, and candy, on a farm in rural Guatemala, and the following day a throng of thousands gathered to watch them die. Residents of some 14 surrounding villages converged on Matucuy, Purulha, Baja Verapaz, to witness the lynching of Jose Ical Xip, 34, Juan Cuc, 23, and Rene Alfredo Cho, 15. Despite failed interventions by local and international human rights authorities, the three were hanged and their bodies burned. By the time the Civilian National Police arrived after fighting off local residents who attempted to hold them at bay, the bodies had been buried and most of those responsible for the lynching had fled. ${ }^{1}$ Enraged by the recent murder of a 6 year-old boy, residents of Mariara, Venezuela, seized upon 41-year-old Omar Perez

\footnotetext{
1 The case has been reported as cited in Godoy, Angelina Snodgrass, "When "Justice" Is Criminal: Lynchings in Contemporary Latin America". Theory and Society, Springer, no.6, vol.33, 2004. (pp. 621651).
} 
Gallardo on April 16, 2001. After dragging him to the boy's house, where the grieving mother claimed to recognize him, the crowd attacked him and would likely have killed him had the Police not arrived to save his life. Later that same night, a crowd of some four to five hundred residents--among them the local mayor--converged on the small hospital where he lay recovering from his wounds, and threatened to set fire to the entire establishment if Mr. Perez was not released. He was subsequently beaten to death in the Plaza Bolivar; one arm was removed from his body and hung in a tree; and the remainder of his cadaver was set afire in the plaza amid a passionate protest against rampant criminal activity in the region. As part of this protest, locals occupied and temporarily closed the regional highway. It was later revealed that Mr. Perez was innocent of all charges; he had apparently been mistaken for a legendary serial killer known as the "Monster of Mariara." 2

Therefore, people's desire for immediate justice - albeit summary - was satisfied by a public execution in which the bodies of the victims (or parts of them) were burnt and hung from trees. They were displayed to warn future potential lawbreakers not to commit more robberies or murders in the territory.

It is also an expression of the lack of trust in government institutions, as they are not considered capable of accepting the need to stop crime with faster sentences and harsher punishments. As a result, vigilantes in Latin America are empowered by most of the population to perpetuate a violent form of local governance that violates constitutions and laws but provides an apparent sense of social security.

\section{POPULAR CONSENSUS}

What happened in Guatemala and Venezuela is reminiscent in its violent method of one of the cases that most shocked public opinion in the United States in 1893 when the lynching of African Americans was on the rise and socially supported:

Henry Smith, the black man who had attacked the little four-year-old Myrtle Vance, was burnt alive, thus partially expelling his crime. [...] When the other night came the news of his capture and his identification by BB Sturgeon, James T. Hicks and many other citizens of Paris who participated in the search the city was rejoicing for the capture of the brute. [...] Everything has been prepared professionally. The agents found the futility of controlling the passions of the crowd, so the law was put aside and the citizens took the situation in their hands and burned the prisoner at the stake. [...] The negro was put, as an object of mockery, on a cart, [...] and followed by the immense crowd was escorted throughout the city. [...]. The victim was tortured for fifty minutes with an incandescent iron, stuck in her trembling body. [...] When he was apparently dead, they poured him some kerosene [...] and set him on fire. Some curious people have already taken away what remained after the memorable event. [...] His clothes were torn and scattered in the crowd, with people taking the shreds and putting them away as a souvenir. [...] Every complaint of the condemned man, every contortion of his body was greeted with applause by the crowd (New York Times, February 2, 1893).

${ }^{2}$ Ibid. 
If, however, in the case of the United States lynching seems to be a practice of colonial origin (Pfeifer, 2011) in which the categories of gender, race and class would be more important than the crime to be condemned, today in Latin America it is the sense of social insecurity that determines when to resort to an extra-legal justice approved by the population.

In When "Justice" Is Criminal: Lynchings in Contemporary Latin America, Godoy (2004, p. 621) argues that "the lynchings suggest an attempt by embattled communities to reassert their autonomy after decades of repeated assault by state armies, local elites, the globalized economy, and other adversaries." Therefore, it would be an attempt by communities far from urban centers to assert their authority to hinder various forms of oppression perceived as criminality.

However, it has also emerged that this is not sufficient to justify the everincreasing number of cases of extra-legal violence (Cruz and Kloppe-Santamaría, 2019). In fact, in accordance with the most recent literature on violence in Latin America (Cruz, 2016; Dewey, 2012; Magaly Sanchez, 2006; Muggah, 2017), it can be observed that today's crime rates should be studied considering more variables and not only the identity of the actors involved. Consequently, attention should be paid to the role that the state and its institutions play in the incidence of violence (Bailey, 2008).

As Cruz and Kloppe-Santamaría (2019, p. 51) convincingly assert, there are three assumptions to start from for an understanding of the widespread approval of today's lynching: insecurity and fear of crime, social inequality, and institutional weakness.

Examining these assumptions in the literature, according to several authors (Godoy, 2004; Rodríguez Guillén, 2012), local crime levels are not enough to support acts of extra-legal violence because also individual subjective experiences and unique perception of danger contribute to the construction of a sense of social insecurity and the consequent fear of crime.

Nevertheless, other factors may come into play. In Chile, for example, unemployment, poverty, or trust in institutions affect the population's fear of being a victim of crime (Dammert and Malone, 2003). On the other hand, in Guatemala, vigilante actions such as lynching are more supported when the level of trust in government institutions wanes, due to the continuous disclosure of crime stories that undermine socio-legal stability (Krause, 2014). Furthermore, economic factors also seem to have significant importance in relation to social inequality and institutional weakness. Historical and sociological explanations related to lynching are varied. However, historians and sociologists agree that if competition between groups for economic and/or political resources increases, intergroup antagonism increases accordingly, generating forms of violence (Higgs, 1977). In line with this perspective, it is possible to assert that severe political instability and economic hardship problems contributed to the spread of lynching in different parts of the world, especially in Latin America. Regardless of geography, there is empirical evidence demonstrating the incidence of economic factors in perceptions of security and vigilantism. Only those living in economic prosperity can afford access to private security forms; otherwise, other solutions must be employed. 
The U.S. case is the best known, wherewith the collapse of the plantation system in the South, two fundamental changes occurred in the area's economy. Firstly, when African Americans started to buy plots of land to grow their own cotton, they began to compete with white farmers to share the market. Second, some blacks migrated to southern manufacturing sectors, competing with white workers for the same jobs. These two factors led to increased competition for resources in the agricultural and manufacturing sectors. Consequently, due to their economic and social ascendancy, whites felt threatened by a growing cheap black labor force and their increased clout - including political influence (James, 1988). Although the economic competition theory seems to be one of the most explanatory of the phenomenon of lynching of African Americans in the United States (Soule, 1992), each episode took place and was of interest in specific circumstances. There may be manifest purposes easily identifiable in words or actions, or latent ones, sometimes with deep and unconscious meanings even for the crowd itself (Thurston, 2011).

The U.S. cases differ somewhat from those in South America. However, many common factors help understand the phenomenon at a global level, such as the role of economic factors. Even in Latin America, to maintain a stable social economic order over time, which would continue to favor the already wealthy classes, the use of violence (Arias and Goldstein, 2010; Benson, Fischer and Thomas, 2008; Costa, 2011), including extra-legal violence, has often been used. Therefore according to Cruz and Kloppe-Santamaría (2019), this form of criminality can be understood as necessary to guarantee and safeguard the interests of an elite class, unwilling to lose the benefits that the position ensures. It is in line with Caldeira's (2001) observation in Brazil, where the wealthy classes did not hesitate to violate human rights by resorting to acts of extreme violence through private security guards and police forces to achieve greater public security that would safeguard them.

It is thus possible to assert that extra-legal violence can be found in any economic context, from the poorest to the wealthiest (Cruz and Kloppe-Santamaría, 2019). However, such actions have significant consequences on political stability. More generally, it is possible to argue that violent cases such as lynching's burden the legal apparatus' sense of justice.

\section{THE NEED FOR GOVERNANCE}

The Latin American government's inability to guarantee fair and impartial justice, on a daily basis, seems to be related to lynching incidents and their associated forms of group violence (Ungar, 2007). This is because of the slowness of the legal system and - at times - impunity. It often happened that the authors of a proven crime were convicted after a long time from the incident. Furthermore, during that time, many criminals awaiting trial continued to commit crimes. As a result, extra-legal violence was approved, supported, and perpetuated by the mob demanding immediate justice.

At the same time, however, the success of governments in coping with a rising 
crime is compromised, as violence seems not to stop even when there is a conviction (Saín, 2006; Ungar, 2007). Thus, democratic governments themselves are allegedly unconscious promoters of summary justice, as punishments that are too late, too light, or not at all, are seen by the population as a failure to take a stand that undermines social security (Whitehead, 2009).

Consequently, the lack of trust in the government leads to a loss of confidence in its institutions, which is why, for example, in Bolivia, Guatemala, and Brazil, several police stations were stormed by citizens even when the law enforcement caught a suspect (Cruz and Kloppe-Santamaría, 2019). Still, believing that an objective punishment would come too late or never, the popular will decided to express itself. It is evidenced by the event reported by Natalie Evans for the Irish Mirror on February 9, 2017, about a sad incident in Brazil:

[...] a furious mob attempted to lynch a suspected arsonist being held in police cells before throwing her onto a BONFIRE. The 30-year-old woman was being held on suspicion of causing a fire that killed a two-year-old boy in Novo Aripuana, Brazil, on Monday. A baying mob of around 500 residents stormed the police station and broke down the doors of the holding cell before dragging her outside on Tuesday afternoon. Locals torched impounded cars to start a make-shift bonfire and pulled the woman by the HAIR onto the roaring flames. [...] Police called for military reinforcements to hold back the mob before the injured woman could be saved and taken to hospital.

Unfortunately, this case is only one of many that involved different areas of Brazil in a real 'lynching epidemic' (Jung and Cohen, 2020, p. 1), with one death every two days in the year before the event (De Oliveira, 2016). The region's administration affects people's perception of safety, which in turn involves the legitimacy of state intervention.

Taking up the thought of Kahler and Lake (2003), enunciated in "Globalization and Governance," Jung and Cohen (2020, p. 10) offer their interpretation of governance, defining it as: "authority in a social relationship in which one actor will voluntarily comply with decisions issued by another," emphasizing the micro-level as the place where actions that convey beliefs trough violence such as lynching are born. In a recent publication, Jung and Cohen (2020) investigated the relationship between governance, perceptions of legitimacy, and support for lynching. Their research shows that the legitimacy of state intervention is less accepted - in contrast to lynching when non-state actors such as vigilantes provide alternative governance services. In this way, extra-legal violence gains rapid acceptance, and state actions are resisted as not being trustworthy. It is along these lines of thinking that the above Brazilian episode occurred. However, it has also been proven that lynching and similar forms can exert long-term adverse social and political effects with consequences for the entire country (Jung and Cohen, 2020).

In the first instance, the frequency with which lynching occurs indicates that many communities decide to punish before an investigation occurs, replacing state action. One example is a case in Bolivia reported in the 2009 U.S. State Department Human Rights Report: 
On April 7, Police in Cochabamba broke up three separate lynching attempts to kill up to ten persons for robberies. In one incident a crowd beat a group of six children ranging in age from fourteen to seventeen, only to find hours later the children were not the thieves ${ }^{3}$.

This episode shows that wrongful convictions often carry out lynching, and the sheer speed with which the act occurs means that summary justice is, in fact, ineffective and unfair since even an innocent person can fall victim of it. All this contributes to the sense of insecurity and uncertainty that the population perceives (Jung and Cohen, 2020), as doubts also arise about the extra-legal violence exercised. However, it continues to be proposed as it is considered more reliable than investigations and the resulting state punishments. Thus, to stop cases of theft or otherwise, actual murders are committed on innocent bodies, fuelling crime instead of fighting it.

Secondly, in the absence of stable governance in which the people have confidence, lynching can also be used to target minority groups, usually hated for several reasons. For example, in Haiti, in 2010: 'At least 45 people, most of them Vodou priests, were lynched since the beginning of the cholera epidemic by angry mobs blaming them for the spread of the disease' (Valme, 2010). According to the Minister of Communications Marie-Laurence Lassegue, it occurred because of the false belief that voodoo practitioners were able to give birth to the disease through acts of witchcraft. Hence, they were the ones who spread it. The hatred aroused in the population led to a mob lynching with the help of sharp weapons and burning to eradicate the source of evil (Valme, 2010).

Lastly, as argued by Jung and Cohen (2020, p. 12), lynching is inefficient. It does not really improve the social situation of a country, as the punishments inflicted by the mob are disproportionate to the crime they accuse, going against all jurisprudence. The cases of Latin America are examples of this. As studied by Sparks and colleagues: "[...] in speaking of crime, people routinely register its entanglement with other aspects of economic, social, and moral life; attribute responsibility and blame; demand accountability and justice; and draw lines of affiliation and distance between 'us' and various categories of 'them'" (2001, p. 896). It is on these assumptions that extra-legal violence will continue to perpetuate over time in any geographical context, as has already happened.

Pearce (2010) observes that in Latin America, with the transition to democracy, forms of extra-legal justice such as lynching would find possibilities of expression because: "The transitions to democracy in Latin America eroded the containment model of authoritarian control and selective violence (against political oppositions and armed insurgents). [...] The outcome, with notable exceptions, has been a truly vicious cycle of violence," where "Access to law remains a privilege in Latin America, as does the ability to manipulate it" (Pearce, 2018, p. 13). Therefore - in many cases - popular

\footnotetext{
${ }^{3}$ The case has been reported as cited in Jung, Danielle F. - Dara Kay, Cohen. Lynching and Local Justice Legitimacy and Accountability in Weak States. Cambridge, Cambridge University Press, 2020, pp. 10-11.
} 
groups are more satisfied with the practice of lynching, as this tool can guarantee an apparent immediate condemnation. The need for a better model of governance that may be more widely shared by the actors in the field, should it also be an achievement by Latin American governments so that the population no longer claims forms of summary justice.

\section{CONCLUSIONS}

This article has observed that in contemporary Latin America, the motivations behind lynching are wide-ranging, from economic to legal-social aspects. However, the population mainly takes refuge behind the need for greater social security. Indeed, Cruz and Kloppe-Santamaría (2019) noted that further research is needed not on the limits of law enforcement in lynching cases but precisely on the relationship between the state and citizens in contesting crime, focusing on the study of the acceptance of the legitimacy of state intervention.

A starting point for future investigations may be the impact that the U.S. federal system had on the constitution of the Latin American one (Rolla, 2010) and its execution, in which it is possible to find common traits under which lynching often finds impunity. In Argentina, for example, the federal courts exercise control over constitutionality, and there is the Supreme Court to regulate and supervise all federal courts. It means that lynching can be discussed in the provincial courts, but not as a federal crime. This is also because, as was often the case in the United States, the charges become kidnapping, torture, or otherwise and consequently treated as such. Moreover, since many people usually carry out lynching together, it is difficult to have a culprit to charge. For these reasons, states struggle to condemn this practice of extralegal violence. At the same time, the mob - unpunished - believes that it is the fairest and quickest solution to repeat to have an immediate sentence that accepts the people's will.

In conclusion, there is a need for a more efficient government administration, able to understand that lynching is now a bottom-up phenomenon (Godoy, 2004). It can be stopped only if social groups return to considering their government fair and incorruptible so that future crimes do not fall into bureaucratic sluggishness, only to end in slight punishment or even impunity.

\section{BIBLIOGRAPHY}

Abrahams, R. (1998). Vigilant citizens: Vigilantism and the state. Malden: Polity Press.

Allen, F. (February 9, 2017). MOB JUSTICE - Lynch mob throw a suspected arsonist on a BONFIRE after she was accused of starting blaze that killed two-year-old boy in Brazil. The Sun. https://www.thesun.co.uk/news/2827214/lynch-mob-throw-a-suspected-arsonist-on-a-bonfireafter-she-was-accused-of-starting-blaze-that-killed-two-year-old-boy-in-brazil/ [Jan. 3, 2021].

Arias, E. D., \& Goldstein, D. M. (2010). Violent Pluralism: Understanding the New Democracies of Latin America. In E. D. Arias \& D. M. Goldstein (Eds.), Violent Democracies in Latin America, 1-34. US: Duke University Press. 
Armanda Global Inc. (2014). Bolivia Security Overview and Travel Assessment. Amizade. https://amizade.org/wp-content/uploads/2014/08/Bolivia-Travel-Assessment-web-siteversion.pdf

Bailey, J. (2008). Violence, State Formation, and Everyday Politics in Latin America. Latin American Research Review, 43 (3), 239-249.

Barbara, V. (2015, Aug. 13). Brazil's Vigilante Lynchings. New York Times. www.nytimes.com/2015/08/14/opinion/vanessa-barbara-brazil-vigilante-lynchings.html

Bateson, R. A. (2013). Order and violence in postwar Guatemala. Yale University, Unpublished PhD thesis.

Bateson, R. (2020). The Politics of Vigilantism. Comparative Political Studies, 54 (6).

BBC Mundo (Jan. 2, 2021). Perú: turba lincha a un alcalde. http://news.bbc.co.uk/hi/spanish/latin_america/newsid_3662000/3662467.stm

Benson, P., Fischer, E. F., \& Thomas, K. (2008). Resocializing Suffering: Neoliberalism, Accusation, and the Sociopolitical Context of Guatemala's New Violence. Latin American Perspectives, 35(5), 38-58.

Berg, M., \& Wendt, S. (2011). Globalizing lynching history: Vigilantism and extralegal punishment from an international perspective. Basingstoke: Palgrave Macmillan.

Cabrera, N. (2018, Dec. 8). Aumentan linchamientos en Venezuela por desconfianza hacia las autoridades. France24.

https://www.france24.com/es/20181208/aqui-america-aumentan-linchamientos-venezuelaimpunidad

Caldeira, T. P. R. (2020). City of Walls: Crime, Segregation, and Citizenship in São Paulo. Berkeley: University of California Press.

Carreras, M. (2013). The Impact Of Criminal Violence On Regime Legitimacy In Latin America. Latin American Research Review, 48(3), 85-107.

Chávez, F. (2013, December 9). "Lynch Mobs Hide Behind 'Community Justice' in Bolivia". http://www.ipsnews.net/2013/12/lynch-mobs-invoke-community-justice-bolivia [Feb. 6, 2021]

Clark, T. (2011). Lynching in Another America: Race, Class, and Gender in Brazil, 1980-2003. In Berg, M. \& S. Wendt (eds) Globalizing Lynching History (pp. 187-205). New York: Palgrave Macmillan.

Consejo de Derechos Humanos (2012). Informe Anual de la Alta Comisionada de las Naciones Unidas para los Derechos Humanos en Bolivia - Report. Bolivia: Consejo de Derechos Humanos.

Costa, A. T. M., \& Thompson, T. (2011). Police Brutality in Brazil: Authoritarian Legacy or Institutional Weakness? Latin American Perspectives, 38(5), 19-32.

Cruz, J.M. (2016). State and Criminal Violence in Latin America. Crime, Law and Social Change, 66 (4), 375-396.

Cruz, J.M. \& Kloppe-Santamaría, G. (2019). Determinants of Support for Extra-legal Violence in Latin America and the Caribbean. Latin American Research Review, 54 (1), 50-67.

Dammert, L., \& Malone, M. F. T. (2003). Fear of Crime or Fear of Life? Public Insecurities in Chile. Bulletin of Latin American Research, 22(1), 79-101.

De Oliveira, C. (2016, Dec. 6). Brazil Grapples with Lynch Mob Epidemic: 'A Good Criminal is a Dead Criminal'. The Guardian.

www.theguardian.com/world/2016/dec/06/brazil-lynch-mobs-vigilante-justice-fortaleza [July 7, 2021]. 
Derpic, J. C. (2015). Twenty-one days of lynching and three jute bags. Collective violence and crime in rural Bolivia. Conference Papers of the American Sociological Association Annual Meeting, 1-16.

Dewey, M. (2012). Illegal Police Protection and the Market for Stolen Vehicles in Buenos Aires. Journal of Latin American Studies, 44(4), 679-702.

Evans, N. (2017, Feb. 9). Mob drags woman accused of killing toddler from prison cell then throws her on a BONFIRE. Irish Mirror.

https://www.irishmirror.ie/news/world-news/lynch-mob-throws-woman-bonfire-9789782 [Jan. 3, 2021].

Rumelili, B., Todd, J., \& Flesken, A. (2010). Identity change in a context of intergroup threat: Regional identity mobilization in Bolivia. Politics \& Society, 38 (1), 51-67.

Gilbert, C. (2017, July 9). Strange Fruit: Venezuela Has an Opposition that Nobody Should Support. Venezuelanalysis.

https://venezuelanalysis.com/analysis/13270 [July 14, 2020].

Sandoval, G. A. B. (January 01, 2007). Taking matters into one's hands: Lynching and violence in postcivil war Guatemala. Urban Anthropology and Studies of Cultural Systems and World Economic Development, 36 (4), 357-379.

Godoy, A. S. (2004). When "Justice" Is Criminal: Lynchings in Contemporary Latin America. Theory and Society, 33(6), 621-651.

Goldstein, D. M. (2003). "In Our Own Hands": Lynching, Justice, and the Law in Bolivia. American Ethnologist, 30(1), 22-43.

González, M. L. S. (2019). Los pueblos y comunidades indígenas de América Latina: Filosofía jurídico-política y derechos (1st ed.). Dykinson, S.L.

Handy, J. (2004). Chicken Thieves, Witches, and Judges: Vigilante Justice and Customary Law in Guatemala. Journal of Latin American Studies, 36(3), 533-561.

Higgs, R. (1977). Competition and coercion: Blacks in the American economy, 1865-1914. New York: Cambridge University Press.

Human Rights Watch (2018). World Report 2018 - Events of 2017. United States of America: Human Rights Watch.

Inter-American Commission on Human Rights (2017). Situation of Human Rights in Guatemala. Guatemala: OAS - Official records.

James, D. R. (1988). The Transformation of the Southern Racial State: Class and Race Detenninants of Local State Structures. American Sociological Review, 53, 191-208.

Jung, D. F. \& Cohen, D. K. (2020). Lynching and Local Justice - Legitimacy and Accountability in Weak States. Cambridge: Cambridge University Press.

Kahler, M. \&, Lake, D. (2003). Globalization and Governance. In Kahler, M. \&, Lake, D. (eds.), Governance in a Global Economy: Political Authority in Transition, Princeton: Princeton University Press, 1-32.

Koonings, K. \& Kruijt, D. (2004). Armed Actors, Organized Violence and State Failure in Latin America: A Survey of Issues and Arguments. In Koonings, K. \& Kruijt, D. (eds.) Armed Actors: Organised Violence and State Failure in Latin America. New York: Zed Books, 5-15.

Krause, K. (2014). Supporting the Iron Fist: Crime News, Public Opinion, and Authoritarian Crime Control in Guatemala. Latin American Politics and Society, 56(1), 98-119.

Lake, D. A. (2010). Rightful Rules: Authority, Order, and the Foundations of Global Governance. International Studies Quarterly, 54(3), 587-613. 
LeBas, A. (September 01, 2013). Violence and Urban Order in Nairobi, Kenya and Lagos, Nigeria. Studies in Comparative International Development, 48, 3, 240-262.

New York Times (1893, Feb. 2). Another Negro Burned - Henry Smith Dies at the Stake - Drawn Through the Streets on a Car - Tortured for Nearly an Hour With Hot Irons and Then Burned Awful Vengeance of a Paris (Texas) Mob.

http://query.nytimes.com/gst/abstract.html?res=9F01E5DE103BEF33A25751C0A9649C94629ED7C F\&legacy=true [June 3, 2021].

Magaly, S. Insecurity and Violence as a New Power Relation in Latin America. The Annals of the American Academy of Political and Social Science, 606 (1), 178-195.

Martell, C. (2019, March 12). Estudio: Las 50 ciudades más violentas del mundo 2018.

http://www.seguridadjusticiaypaz.org.mx/seguridad/1567-estudio-las-50-ciudades-mas-violentasdel-mundo-2018 [June 28, 2021].

Mazzei, J. (2009). Death Squads or Self-defense Forces? How Paramilitary Groups Emerge and Challenge Democracy in Latin America. Chapel Hill: University of North Carolina Press.

Melgar, I. $(2013,11)$. Los primeros 100 días: autodefensa, riesgo para gobernabilidad. http://www.excelsior.com.mx/2013/03/11/888371 [Jan. 3, 2021].

MINUGUA (202). Los Linchamientos: Un Flagelo que Persiste. Guatemala: Misión de Verificación de las Naciones Unidas en Guatemala.

Moncada, E. (2017). Varieties of vigilantism: Conceptual discord, meaning, and strategies. Global Crime, 18 (4), 403-423.

Morelli, F. (2007). Orígenes y valores del municipalismo iberoamericano. Araucaria - Revista Iberoamericana de Filosofía, Política y Humanidades, 9 (18). https://idus.us.es/bitstream/handle/11441/46005/file_1.pdf?sequence=1 [July 24, 2021]

Muggah, R. (2017). The Rise of Citizen Security in Latin America and the Caribbean. In G. Carbonnier, H. Campodónico, \& S. T. Vázquez (Eds.), Alternative Pathways to Sustainable Development: Lessons from Latin America (pp. 291-322). Netherlands: Brill.

Muñoz Pandiella, L. (2020, June 4). América Latina tiene 42 de las 50 ciudades más violentas del mundo. France24.

https://www.france24.com/es/20200604-america-latina-50-ciudades-violentas-mundo [Feb. 22, 2021]

Pearce, J. (2018). Elites and Violence in Latin America - Logics of the Fragmented Security State. Violence, Security, and Peace Working Papers, 1, 3-28.

Pearce, J. (2010). Perverse State Formation and Securitized Democracy in Latin America. Democratization, 17 (2), 286-306.

Peregil, F. (2014, Apr. 4). Argentina se estremece ante la irrupción de varios linchamientos a ladrones. El Pais. https://elpais.com/internacional/2014/04/04/actualidad/1396625984_568501.html [June 19, 2021]

Pfeifer, M. (2017). Global Lynching and Collective Violence: Volume 1: Asia, Africa, and the Middle East. Champaign: University of Illinois Press.

Pfeifer, M. (2017). Global Lynching and Collective Violence: Volume 2: The Americas and Europe. Champaign: University of Illinois Press.

Pfeifer, M. (2011). The Roots of Rough Justice: Origins of American Lynching. Champaign: University of Illinois Press.

Observatorio Venezolano de Conflictividad Social (2017, Nov. 22). Linchamientos e intentos de linchamiento en Venezuela 2017. 
https://www.observatoriodeconflictos.org.ve/derechos-humanos/200-casos-de-linchamientos-eintentos-en-venezuela-en-2017 [Jan. 5, 2021]

Prillaman, W. C. (2000). The Judiciary and Democratic Decay in Latin America. Westport: Praeger.

Rodríguez Guillén, R. (2012). Crisis de autoridad y violencia social: Los linchamientos en México. Polis: Investigación y Análisis Sociopolítico y Psicosocial, 8 (2), 43-74.

Rojas, G. (2010, Sept. 15) Linchamiento: una familia entierra vivos a tres hermanos por 'venganza'. https://eju.tv/2010/09/linchamiento-una-familia-entierra-vivos-a-tres-hermanos-por-venganza/ [June 22, 2021]

Rolla, G. (2010). L'evoluzione del costituzionalismo in America latina e l'originalità delle esperienze di giustizia costituzionale. Studi urbinati di scienze giuridiche politiche ed economiche, 61, 575-599.

Rosenbaum, H. J., \& Sederberg, P. C. (1974). Vigilantism: An Analysis of Establishment Violence. Comparative Politics, 6(4), 541-570.

Saccone, V. (2017, June 22). Brasil, a la cabeza del mundo en linchamientos. https://www.elconfidencial.com/mundo/2017-06-22/brasil-linchamientos-cabeza-estadisticasmundiales_1402709/ [July 22, 2021]

Saín, M. (2004). A Failed State Facing New Criminal Problems: The Case of Argentina. In Koonings, K. \& Kruijt, D. (eds.) Armed Actors: Organised Violence and State Failure in Latin America. New York: Zed Books, 127-138.

Schemo, D.J. (1996, May 13). Lynch-Mob Justice Grows in Caracas. New York Times.

Soule, S. A. (1992). Populism and Black Lynching in Georgia, 1890-1900. Social Forces, 71 (2), 431-449.

Sparks, R., Girling, E., \& Loader, I. (January 01, 2001). Fear and everyday urban lives. Urban Studies, 38 (5), 885-898.

Stavenhagen, R. (2005). The Rights of Indigenous Peoples: Closing a Gap in Global Governance. Global Governance, $11(1), 17-23$.

Sundar, N. (2010). Vigilantism, Culpability and Moral Dilemmas. Critique of Anthropology, 30 (1), 113121.

Thurston, R. W. (2011). Lynching: American Mob Murder in Global Perspective. Burlington: Ashgate Publishing.

Ungar, M. (2007). The Privatization of Citizen Security in Latin America: From Elite Guards to Neighborhood Vigilantes. Social Justice (34), 20-34.

United Nations Office on Drugs and Crime (2014). Global Study on Homicide 2013. United Nations publication, 4(14).

Valme, J. M. (2010, Dec. 24). Officials: 45 people lynched in Haiti amid cholera fears. CNN. http://edition.cnn.com/2010/WORLD/americas/12/24/haiti.cholera.killings/index.html [Jan. 5, 2021].

Venezuela Investigative Unit (2017, Jan. 19). Lynchings Jump 650\% in Venezuela in 2016. https://www.insightcrime.org/news/analysis/lynchings-jump-650-percent-venezuela-2016/ [July 12, 2021].

Waldrep, C. (2002). The Many Faces of Judge Lynch - Extra-legal Violence and Punishment in America. US: Palgrave Macmillan.

Weston, G. (2020). Guatemalan Vigilantism and the Global (Re)Production of Collective Violence, $A$ Tale of Two Lynchings. UK: Routledge. 
Whitehead, L. (2009). The Privatization of Citizen Security in Latin America: From Elite Guards to Neighborhood Vigilantes. In Bergman, M. \& Laurence, Whitehead, L. (eds.) Criminality, Public Security, and the Challenge to Democracy in Latin America. Notre Dame: University of Notre Dame Press, 277-314.

Yates, D. (2020). Community Justice, Ancestral Rights, and Lynching in Rural Bolivia. Race and Justice, $10(1), 3-19$.

Zizumbo-Colunga, D. (2010). Explaining Support for Vigilante Justice in Mexico. AmericasBarometer Insights, 39. https://www.vanderbilt.edu/lapop/insights/I0839en.pdf [July 3, 2021].

Giovanni Battista CORVINO is Ph.D. Candidate in Global History of Empires at Turin University - joint doctoral program with the Higher School of Economics (Moscow and St. Petersburg, Russian Federation). He was Visiting Fellow at the Roosevelt Institute for American Studies (the Netherlands, 2019). Recently, he was Visiting Assistant in Research at Yale University - Department of African American Studies, where he worked on the evolution of the concept of civil and human rights in the United States through the lynching of African Americans (1940-1960). 